\title{
POREJESTRACYJNE BADANIA BEZPIECZEŃSTWA PRODUKTÓW LECZNICZYCH W SYSTEMIE PHARMACOVIGILANCE
}

\begin{abstract}
Streszczenie. Celem artykułu jest przedstawienie prawnych uwarunkowań jednego z elementów systemu pharmacovigilance (bezpieczeństwa farmakoterapii) - porejestracyjnych badań bezpieczeństwa produktów leczniczych. Analizie poddano wymogi oraz zasady prowadzenia badań bezpieczeństwa produktów leczniczych po wydaniu pozwolenia na dopuszczenie ich do obrotu w świetle obowiązujących przepisów prawnych, w szczególności ustawy z dnia 6 września 2001 r. Prawo farmaceutyczne.
\end{abstract}

Słowa kluczowe: porejestracyjne badania, bezpieczeństwo produktów leczniczych, bezpieczeństwo farmakoterapii, pharmacovigilance, produkty lecznicze, bezpieczeństwo leków.

\section{WPROWADZENIE}

System nadzoru nad bezpieczeństwem stosowania produktów leczniczych, określany w regulacjach unijnych terminem pharmacovigilance, etymologicznie pochodzącym od greckiego słowa pharmakon - 'lek' oraz od łacińskiego słowa vigilare - 'obserwować, zachować czujność', to system wykorzystywany przez podmioty odpowiedzialne oraz właściwe organy do wypełniania zadań w zakresie bezpieczeństwa farmakoterapii, w szczególności mający na celu monitorowanie bezpieczeństwa stosowania dopuszczonych do obrotu produktów leczniczych oraz wykrywanie wszelkich zmian w ich stosunku korzyści do ryzyka, a także obligujący różne podmioty rynku farmaceutycznego do podejmowania działań zmniejszających ryzyko związane ze stosowaniem leków. Legalną definicję „systemu nadzoru nad bezpieczeństwem stosowania produktów leczniczych" zawiera art. 2 pkt 40c ustawy z dnia 6 września 2001 r. Prawo farmaceutyczne (tekst jedn. Dz.U. z 2019 r., poz. 499 ze zm.). Uzyskanie kompletnej wiedzy w zakresie bezpieczeństwa stosowania produktów leczniczych za pomocą zróżnicowanych mechanizmów oceny bezpieczeństwa stosowania leku jest niezbędne dla zapewnienia właściwej ochrony życia i zdrowia ludzkiego. Nie tylko bowiem ułatwia dobór odpowiedniego produktu leczniczego konkretnemu pacjentowi, ale pozwala

${ }^{*}$ Uniwersytet Łódzki, Wydział Prawa i Administracji, Katedra Prawa Administracyjnego i Nauki Administracji, arabiega@wpia.uni.lodz.pl. 
również na podjęcie odpowiednich działań w przypadkach wystąpienia niepożądanych objawów produktu leczniczego (Maciejczyk 2008, 39).

Zgodnie z art. 101 Dyrektywy 2001/83/WE Parlamentu Europejskiego i Rady z dnia 6 listopada 2001 r. w sprawie wspólnotowego kodeksu odnoszącego się do produktów leczniczych stosowanych u ludzi (Dz.Urz. UE L z 2001 r. Nr 311.67; dalej: dyrektywa 2001/83/WE) system nadzoru nad bezpieczeństwem farmakoterapii wykorzystuje się do zbierania informacji na temat zagrożeń związanych z produktami leczniczymi ze względu na zdrowie pacjentów lub zdrowie publiczne. Informacje te odnoszą się w szczególności do działań niepożądanych występujących u ludzi, wynikających ze stosowania produktu leczniczego zgodnie z warunkami pozwolenia na dopuszczenie do obrotu oraz ze stosowania produktu poza warunkami określonymi w pozwoleniu na dopuszczenie do obrotu, a także do działań niepożądanych związanych $\mathrm{z}$ narażeniem zawodowym. Za pomocą systemu nadzoru nad bezpieczeństwem farmakoterapii państwa członkowskie dokonują naukowej oceny wszystkich informacji, rozważają możliwości minimalizacji ryzyka i jego zapobiegania, a $\mathrm{w}$ razie konieczności podejmują działania regulacyjne $\mathrm{w}$ odniesieniu do pozwolenia na dopuszczenie do obrotu (art. 101 ust. 1-2 dyrektywy 2001/83/WE). Obecnie obowiązujący system pharmacovigilance w Unii Europejskiej został określony Dyrektywą Parlamentu Europejskiego i Rady 2010/84/UE zmieniającą - w zakresie nadzoru nad bezpieczeństwem farmakoterapii - dyrektywę 2001/83/WE w sprawie wspólnotowego kodeksu odnoszącego się do produktów leczniczych stosowanych u ludzi (Dz.Urz. UE L z 2010 r. Nr 348.74; dalej: dyrektywa 2010/84/UE) oraz rozporządzeniem Parlamentu Europejskiego i Rady 1235/2010 zmieniającym - w zakresie nadzoru nad bezpieczeństwem farmakoterapii w odniesieniu do produktów leczniczych stosowanych u ludzi - rozporządzenie (WE) nr 726/2004 ustanawiające wspólnotowe procedury wydawania pozwoleń dla produktów leczniczych stosowanych u ludzi i do celów weterynaryjnych i nadzoru nad nimi oraz ustanawiające Europejską Agencję Leków i rozporządzenie (WE) nr 1394/2007 w sprawie produktów leczniczych terapii zaawansowanej (Dz.Urz. UE L z 2010 r. Nr 348.1). Przepisy unijne (z wyłączeniem rozporządzenia unijnego bezpośrednio obowiązującego na terytorium państw członkowskich) implementowano do prawa polskiego ustawą z dnia 27 września 2013 r. o zmianie ustawy - Prawo farmaceutyczne oraz niektórych innych ustaw (Dz.U. z 2013 r., poz. 1245), wprowadzającą do ustawy Prawo farmaceutyczne rozdział $2^{1}$ dotyczący nadzoru nad bezpieczeństwem stosowania produktów leczniczych. Przewiduje on zróżnicowane mechanizmy nadzoru nad bezpieczeństwem stosowania leków, nakładające na określone podmioty rynku farmaceutycznego obowiązki w zakresie monitorowania niepożądanych działań produktów leczniczych, oceny zagrożeń i korzyści ze stosowania danego produktu leczniczego, dostarczające dane niezbędne do oceny bezpieczeństwa leku już po jego wprowadzeniu do obrotu. Wprawdzie na ocenę bezpieczeństwa 
stosowania leku składają się wyniki badań przedklinicznych i klinicznych, ale nie mniej istotne znaczenie mają dane uzyskane już po wprowadzeniu produktu leczniczego do obrotu w ramach obowiązującego systemu zgłaszania i raportowania działań niepożądanych produktów leczniczych, a także z tzw. porejestracyjnych badań bezpieczeństwa produktów leczniczych.

Niniejszy artykuł ma na celu przedstawienie prawnych uwarunkowań instytucji porejestracyjnych badań bezpieczeństwa produktów leczniczych z uwzględnieniem obligatoryjnego oraz fakultatywnego jej charakteru i próbę oceny przyjętych rozwiązań, także przez pryzmat praktycznego wykorzystywania instytucji porejestracyjnych badań bezpieczeństwa na polskim rynku farmaceutycznym.

\section{POREJESTRACYJNE BADANIA BEZPIECZEŃSTWA PRODUKTÓW LECZNICZYCH JAKO ŹRÓDLO OCENY BEZPIECZEŃSTWA FARMAKOTERAPII}

\subsection{Pojęcie porejestracyjnych badań bezpieczeństwa produktów leczniczych}

Porejestracyjne badania bezpieczeństwa produktów leczniczych, określane w przepisach jako „badania dotyczące bezpieczeństwa przeprowadzane po wydaniu pozwolenia na dopuszczenie do obrotu" (ang. Post-Authorisation Safety Studies - PASS), stanowią istotny element systemu nadzoru nad bezpieczeństwem stosowania produktów leczniczych, zwanym bezpieczeństwem farmakoterapii. Na gruncie przepisów unijnych i krajowych (polskich) definiuje się je jako: każde badanie dotyczące dopuszczonego do obrotu produktu leczniczego, prowadzone w celu zidentyfikowania, opisania lub ilościowego określenia ryzyka, potwierdzenia profilu bezpieczeństwa tego produktu leczniczego lub pomiaru skuteczności środków zarządzania ryzykiem użycia produktu leczniczego (art. 2 pkt la ustawy Prawo farmaceutyczne, art. 1 pkt 15 dyrektywy 2001/83/WE). Badania te to zazwyczaj badania obserwacyjne, mające na celu zbieranie danych od pacjentów i osób wykonujących zawody medyczne, a więc umożliwiające ocenę bezpieczeństwa produktów leczniczych w codziennej praktyce medycznej. Mogą one przybierać postać zarówno biernej obserwacji poprzez pasywny system nadzoru nad zdarzeniami niepożądanymi związanymi ze stosowaniem produktu leczniczego, jak i aktywnej obserwacji poprzez kontrolę pacjentów leczonych danym produktem leczniczym za pomocą systemu zarządzania ryzykiem (European Medicines Agency 2017, 23 i n.). Badanie to określa się mianem badania nieinterwencyjnego, które zgodnie z nowym, choć formalnie jeszcze niestosowanym rozporządzeniem Parlamentu Europejskiego i Rady (UE) nr 536/2014 w sprawie badań klinicznych produktów leczniczych stosowanych u ludzi oraz uchylenia dyrektywy 2001/20/WE (Dz.Urz. UE L z 2014 r. Nr 158.1; dalej: rozporządzenie 536/2014) definiowane jest jako badanie biomedyczne inne niż badanie kliniczne (art. 2 ust. 2 pkt 4 rozporządzenia 536/2014). Tak sformułowana negatywna 
definicja badania nieinterwencyjnego narzuca konieczność sięgnięcia do definicji zarówno badania biomedycznego, jak i klinicznego. Badaniem biomedycznym jest „każde badanie dotyczące ludzi, mające na celu:

a) odkrycie lub potwierdzenie klinicznych, farmakologicznych lub innych farmakodynamicznych skutków jednego lub większej liczby produktów leczniczych;

b) stwierdzenie wszelkich działań niepożądanych jednego lub większej liczby produktów leczniczych; lub

c) zbadanie wchłaniania, dystrybucji, metabolizmu i wydalania jednego lub większej liczby produktów leczniczych; mające na celu upewnienie się co do bezpieczeństwa lub skuteczności tych produktów leczniczych" (art. 2 ust. 2 pkt 1 rozporządzenia 536/2014).

Badaniem klinicznym z kolei jest „badanie biomedyczne spełniające którykolwiek z następujących warunków:

a) przydział uczestnika do danej strategii terapeutycznej ustalany jest z góry i odbywa się w sposób niestanowiący standardowej praktyki klinicznej zainteresowanego państwa członkowskiego;

b) decyzja o przepisaniu badanego produktu leczniczego jest podejmowana łącznie z decyzją o włączeniu uczestnika do badania biomedycznego; lub

c) oprócz standardowej praktyki klinicznej u uczestników wykonuje się dodatkowe procedury diagnostyczne lub procedury monitorowania" (art. 2 ust. 2 pkt 2 rozporządzenia 536/2014).

W konsekwencji, podejmując próbę rozwinięcia wskazanej w rozporządzeniu 536/2014 negatywnej definicji badania nieinterwencyjnego, można uznać, że jest nim badanie biomedyczne, w którym przydzielenie osoby do danej strategii terapeutycznej nie następuje z góry, ale zależy od aktualnej praktyki klinicznej, ponadto decyzja o przepisaniu leku jest niezależna od decyzji o włączeniu osoby do badania biomedycznego, a wobec osób włączonych do badania stosuje się standardową praktykę kliniczną. W zasadzie analogiczną definicję badania nieinterwencyjnego z jednoczesnym wyłączeniem stosowania do nich przepisów dotyczących badań klinicznych przewiduje art. 37al ust. 1 ustawy Prawo farmaceutyczne, zgodnie z którym w badaniach nieinterwencyjnych:

1) produkty lecznicze są stosowane w sposób określony w pozwoleniu na dopuszczenie do obrotu;

2) przydzielenie chorego do grupy, w której stosowana jest określona metoda leczenia, nie następuje na podstawie protokołu badania, ale zależy od aktualnej praktyki, a decyzja o podaniu leku jest jednoznacznie oddzielona od decyzji o włączeniu pacjenta do badania;

3) u pacjentów nie wykonuje się żadnych dodatkowych procedur diagnostycznych ani monitorowania, a do analizy zebranych danych stosuje się metody epidemiologiczne.

W przypadku, gdy w porejestracyjnych badaniach biomedycznych produkty lecznicze byłyby stosowane w sposób odmienny niż określony w pozwoleniu, 
w celu zbadania/odkrycia np. nowych wskazań, nowych sposobów aplikowania, nowych składów, powinny być zakwalifikowane jako badania kliniczne (Miłowska, Zięcik 2016) i w trybie przewidzianym dla badań klinicznych - rejestrowane i prowadzone.

\subsection{Porejestracyjne badania produktów leczniczych - obowiązek czy możliwość?}

Omawiane w niniejszym opracowaniu badania bezpieczeństwa produktu leczniczego prowadzone po wydaniu pozwolenia na wprowadzenie tego produktu do obrotu (PASS), kwalifikowane w literaturze jako odmiana badania nieinterwencyjnego (Masełbas 2016), mogą być prowadzone jako wypełnienie warunków nałożonych na podmiot odpowiedzialny w samym pozwoleniu na dopuszczenie produktu leczniczego do obrotu lub też w ramach obowiązków nałożonych na podmiot odpowiedzialny po wydaniu pozwolenia, lub z inicjatywy podmiotu odpowiedzialnego.

Możliwość wydania pozwolenia na dopuszczenie do obrotu produktu leczniczego z zastrzeżeniem spełnienia dodatkowych warunków dotyczących bezpieczeństwa produktów przewidziano w art. 23b i art. 23c ustawy Prawo farmaceutyczne, implementujących odpowiednie przepisy unijne w tym zakresie. Zgodnie $\mathrm{z}$ art. $23 \mathrm{~b}$ tej ustawy, stanowiącym implementację regulacji art. 22 dyrektywy 2001/83/WE, Prezes Urzędu Rejestracji Produktów Leczniczych, Wyrobów Medycznych i Produktów Biobójczych w wyjątkowych okolicznościach, po konsultacji z podmiotem odpowiedzialnym, może wydać pozwolenie na dopuszczenie do obrotu produktu leczniczego, z zastrzeżeniem spełnienia przez podmiot odpowiedzialny, w wyznaczonym terminie, warunków określonych na podstawie wymagań zawartych w załączniku nr I do dyrektywy 2001/83/WE, a w przypadku produktu leczniczego weterynaryjnego - na podstawie wymagań zawartych w załączniku I do dyrektywy 2001/82/WE w szczególności dotyczących bezpieczeństwa stosowania produktu leczniczego, zgłoszenia działań niepożądanych związanych $\mathrm{z}$ tym produktem oraz podjęcia $\mathrm{w}$ takich przypadkach określonych czynności. Poza ogólnym wskazaniem, czego mogą dotyczyć warunki, do których spełnienia byłby zobowiązany podmiot odpowiedzialny, określając je jako „dotyczące bezpieczeństwa stosowania produktów leczniczych”, ustawodawca nie doprecyzował ich szczegółowo. Można w tym zakresie jedynie odnieść się do brzmienia załącznika I do dyrektywy 2001/83/WE, wskazującego możliwość przyznania pozwolenia na dopuszczenie do obrotu z zastrzeżeniem ,pewnych szczególnych zobowiązań”, mogących zawierać zobowiązania, że m.in. wnioskodawca kończy określony program badań, w czasie określonym przez właściwe organy, których wynik tworzą podstawy ponownej oceny profilu korzyści i ryzyka (część II pkt 6). Przesłanką niezbędną do wydania pozwolenia na dopuszczenie do obrotu produktów leczniczych (z wyłączeniem produktów weterynaryjnych) w trybie przewidzianym przez art. 23b ustawy Prawo farmaceutyczne, 
tj. z zastrzeżeniem warunków m.in. dotyczących bezpieczeństwa stosowania produktu leczniczego, jest wykazanie przez podmiot odpowiedzialny, że z przyczyn obiektywnych i możliwych do zweryfikowania nie jest w stanie dostarczyć kompleksowych danych na temat bezpieczeństwa stosowania i skuteczności produktu leczniczego w normalnych warunkach jego stosowania. Szerzej przyczyny niemożności dostarczenia kompleksowych danych określa wymieniony załącznik I do dyrektywy 2001/83/WE (część II pkt 6), stanowiąc, że wnioskodawca może wykazać, że nie jest w stanie dostarczyć wyczerpujących danych na temat skuteczności i bezpieczeństwa dla normalnych warunków stosowania, ponieważ:

- wskazania, dla których produkt leczniczy jest przewidziany, występują tak rzadko, że nie można racjonalnie oczekiwać, że wnioskodawca może przedstawić wyczerpujące dowody;

- przy obecnym stanie wiedzy naukowej nie można przedstawić wyczerpujących informacji;

- byłoby sprzeczne z ogólnie przyjętymi zasadami etyki lekarskiej zbieranie takich informacji, może zostać przyznane pozwolenie na dopuszczenie do obrotu z zastrzeżeniem pewnych szczególnych zobowiązań.

Pozwolenie na dopuszczenie produktu leczniczego do obrotu, wydawane po konsultacji z podmiotem odpowiedzialnym, przyjmuje postać decyzji warunkowej, przewidującej obowiązek spełnienia w wyznaczonym terminie określonych warunków dotyczących bezpieczeństwa produktu (Jagielska 2015, 259). Przy czym ustawodawca wskazał, że pozwolenie podlega weryfikacji co 12 miesięcy, począwszy od dnia jego wydania (art. 23b ust. 2 ustawy Prawo farmaceutyczne), pomijając wyraźnie możliwość weryfikacji pozwolenia po upływie terminu wyznaczonego na spełnienie zastrzeżonych warunków.

Możliwość wydania pozwolenia na dopuszczenie do obrotu produktu leczniczego, określającego konieczność spełnienia przez podmiot odpowiedzialny dodatkowych warunków, przewiduje również art. 23c tejże ustawy. W odróżnieniu od omówionego wcześniej art. 23b nie dotyczy on sytuacji niemożności dostarczenia kompleksowych danych na temat skuteczności i bezpieczeństwa produktu leczniczego w normalnych warunkach stosowania, ale przypadków, gdy z uwagi na zdrowie publiczne konieczne jest uzupełnienie danych dostępnych w momencie wydawania pozwolenia o dodatkowe dane dotyczące bezpieczeństwa, a w niektórych przypadkach o dane dotyczące skuteczności dopuszczonych do obrotu produktów leczniczych (tak pkt 9 preambuły dyrektywy 2010/84/UE zmieniającej w zakresie nadzoru nad bezpieczeństwem farmakoterapii - dyrektywę 2001/83/WE w sprawie wspólnotowego kodeksu odnoszącego się do produktów leczniczych stosowanych u ludzi). Zgodnie z art. 23c ustawy Prawo farmaceutyczne, stanowiącym implementację regulacji art. 21a dyrektywy 2001/83/WE, „W celu zapewnienia właściwego poziomu nadzoru nad bezpieczeństwem stosowania produktu leczniczego, Prezes Urzędu [Prezes Urzędu Rejestracji Produktów Leczniczych, Wyrobów Medycznych i Produktów Biobójczych - przyp. A.R.-P.], 
może wydać pozwolenie, $\mathrm{z}$ wyłączeniem pozwolenia dla produktu leczniczego weterynaryjnego, w którym określa konieczność spełnienia przez podmiot odpowiedzialny $\mathrm{w}$ określonym terminie warunków: [...] 2) przeprowadzenia badań dotyczących bezpieczeństwa po wydaniu pozwolenia [...]".

Obowiązek przeprowadzenia porejestracyjnych badań bezpieczeństwa produktu leczniczego może zostać nałożony również po wydaniu pozwolenia na wprowadzenie tego produktu do obrotu. Zgodnie z art. 23d ust. 1 ustawy Prawo farmaceutyczne, stanowiącym implementację regulacji art. 22a dyrektywy 2001/83/WE, po wydaniu pozwolenia, z wyłączeniem pozwolenia dla produktu leczniczego weterynaryjnego, Prezes Urzędu Rejestracji Produktów Leczniczych, Wyrobów Medycznych i Produktów Biobójczych może wezwać podmiot odpowiedzialny m.in. do przeprowadzenia badania dotyczącego bezpieczeństwa, jeżeli istnieją obawy dotyczące ryzyka związanego z tym produktem leczniczym. Upoważnienie do nałożenia na posiadacza pozwolenia na dopuszczenie do obrotu obowiązku przeprowadzenia badań dotyczących bezpieczeństwa po wydaniu pozwolenia uzasadniano również względami „zdrowia publicznego” i koniecznością uzupełnienia danych dostępnych $w$ momencie wydawania pozwolenia o dodatkowe dane dotyczące bezpieczeństwa (pkt 9 preambuły dyrektywy 2010/84/UE). Ustawodawca jako uzasadnienie dla nałożenia tego obowiązku wskazał obawy dotyczące ryzyka związanego z tym produktem leczniczym, przy czym wyraźnie sformułował wymóg uzasadnienia konieczności przeprowadzenia tych badań oraz określenia terminu ich przeprowadzenia i przedstawienia protokołów badań (art. 23d ust. 1 in fine ustawy Prawo farmaceutyczne). W konsekwencji to w wezwaniu do przeprowadzenia badań porejestracyjnych, będącym z formalnego punktu widzenia czynnością materialno-techniczną (Jabłoński 2016, 315), organ uzasadnia konieczność przeprowadzenia badań, wskazuje termin ich przeprowadzenia i przedstawienia protokołów badań. Podmiot odpowiedzialny może wystąpić, w terminie 30 dni od dnia doręczenia wezwania do Prezesa Urzędu Rejestracji Produktów Leczniczych, Wyrobów Medycznych i Produktów Biobójczych, z pisemnym wnioskiem o wyznaczenie terminu do ustosunkowania się do wezwania (art. 23d ust. 2 ustawy Prawo farmaceutyczne). Jeżeli podmiot nie wniesie takiego wniosku, obowiązek przeprowadzenia badań określony w wezwaniu jest wiążący, bez potwierdzania go formalnie decyzją administracyjną. Natomiast w przypadku otrzymania wniosku o wyznaczenie terminu do ustosunkowania się do wezwania Prezes Urzędu wyznacza taki termin podmiotowi odpowiedzialnemu. Po bezskutecznym jego upływie albo po otrzymaniu ustosunkowania się do wezwania Prezes Urzędu potwierdza konieczność przeprowadzenia badań albo odstępuje od tego wymogu. Konieczność przeprowadzenia badań wraz z określeniem celu ich przeprowadzenia znajduje potwierdzenie w decyzji administracyjnej. W przypadku odstąpienia od wymogu przeprowadzenia badań Prezes Urzędu pisemnie informuje o tym podmiot odpowiedzialny. Po doręczeniu decyzji o konieczności przeprowadzenia badań wraz z określeniem celu ich przeprowadzenia podmiot 
odpowiedzialny składa niezwłocznie do Prezesa Urzędu wniosek o dokonanie zmiany systemu zarządzania ryzykiem użycia produktu leczniczego. Po otrzymaniu wyżej wymienionego wniosku Prezes Urzędu zmienia pozwolenie na dopuszczenie do obrotu w zakresie określonym w decyzji o konieczności przeprowadzenia badań (art. 23d ustawy Prawo farmaceutyczne). Przewidziane przez ustawodawcę w odniesieniu do wskazanej procedury odstępstwa od modelowego postępowania administracyjnego, chociażby w odniesieniu do formuły informowania o odstąpieniu od przeprowadzenia badań z pominięciem formy rozstrzygnięcia procesowego, może wywoływać wątpliwości co do pewności prawnej w przypadku przesłania takiej informacji (Jabłoński 2016, 316-317).

Porejestracyjne badania dotyczące bezpieczeństwa produktów mogą być również prowadzone dobrowolnie, z inicjatywy podmiotu odpowiedzialnego. Niezależnie od tego, czy badanie bezpieczeństwa następuje na podstawie decyzji podmiotu odpowiedzialnego, czy w wykonaniu obowiązków nałożonych przez organ administracji publicznej, do jego prowadzenia niezbędne jest spełnienie określonych wymogów formalnych. Zgodnie z art. 36u ust. 2 ustawy Prawo farmaceutyczne, podmiot odpowiedzialny, który ma zamiar przeprowadzić badanie dotyczące bezpieczeństwa przeprowadzane po wydaniu pozwolenia, składa protokół tego badania do Prezesa Urzędu (w przypadku prowadzenia badania wyłącznie na terytorium Rzeczypospolitej Polskiej) lub do Komitetu do spraw Oceny Ryzyka w ramach Nadzoru nad Bezpieczeństwem Farmakoterapii (w przypadku prowadzenia badania $\mathrm{w}$ więcej niż jednym państwie członkowskim Unii Europejskiej lub państwie członkowskim EFTA). W przypadku stwierdzenia przez Prezesa Urzędu, że złożony protokół badania wskazuje, iż stanowi ono reklamę, odmawia on, w drodze decyzji, wydania pozwolenia na prowadzenie tego badania (art. 36u ust. 3 pkt 1 ustawy Prawo farmaceutyczne). Z kolei brak spełnienia przez protokół badania celów badania skutkuje wezwaniem przez Prezesa Urzędu do dostarczenia informacji uzupełniających, niezbędnych do wydania decyzji dotyczącej badania, natomiast niespełnienie kryteriów badania dotyczącego bezpieczeństwa, przeprowadzanego po wydaniu pozwolenia, skutkuje wydaniem decyzji odmownej w tym zakresie i np. przekazaniem podmiotowi odpowiedzialnemu informacji, że badanie jest badaniem klinicznym, do którego mają zastosowanie przepisy dotyczące badań klinicznych (art. 36u ust. 3 pkt 2-3 ustawy Prawo farmaceutyczne). Badanie dotyczące bezpieczeństwa przeprowadzane po wydaniu pozwolenia może być rozpoczęte po: zatwierdzeniu protokołu badania i wydaniu przez Prezesa Urzędu, w drodze decyzji, pozwolenia na prowadzenie tego badania, zatwierdzeniu przez Komitet do spraw Oceny Ryzyka w ramach Nadzoru nad Bezpieczeństwem Farmakoterapii protokołu badania w odniesieniu do badań prowadzonych w dwóch lub więcej państwach członkowskich UE/EFTA (art. 36u ust. 4-5 ustawy Prawo farmaceutyczne). Zgodnie z art. 36u ust. 6-8 ustawy Prawo farmaceutyczne podmiot odpowiedzialny prowadzący na terytorium Rzeczypospolitej Polskiej badanie dotyczące bezpieczeństwa zobowiązany jest przedstawiać 
Prezesowi Urzędu sprawozdania z postępów badania, a także wszelkie istotne informacje, które mogą mieć wpływ na ocenę stosunku korzyści do ryzyka użycia danego produktu leczniczego oraz raport końcowy $\mathrm{z}$ badania wraz ze streszczeniem jego wyników w terminie 12 miesięcy od dnia zakończenia gromadzenia danych. Łącznie z raportem końcowym podmiot odpowiedzialny przesyła drogą elektroniczną streszczenie wyników tego badania.

Niezależnie od tego, czy badanie bezpieczeństwa produktów leczniczych prowadzone jest $\mathrm{z}$ inicjatywy podmiotu odpowiedzialnego, czy też w ramach wykonania obowiązku nałożonego przez właściwy organ, uzyskanie w toku badania informacji, mających wpływ na bezpieczeństwo stosowania leku, obliguje podmiot odpowiedzialny do podjęcia określonych kroków. W takiej sytuacji podmiot odpowiedzialny zobowiązany jest do wystąpienia z wnioskiem do Prezesa Urzędu Rejestracji Produktów Leczniczych, Wyrobów Medycznych i Produktów Biobójczych o dokonanie odpowiednich zmian w pozwoleniu na dopuszczenie do obrotu (art. 36x ust. 3 ustawy Prawo farmaceutyczne). Jeżeli informacje te wskazują na istnienie istotnego zagrożenia dotyczącego bezpieczeństwa stosowania produktu, podmiot odpowiedzialny zobowiązany jest również do wprowadzenia stosownych tymczasowych ograniczeń stosowania produktu leczniczego ze względów bezpieczeństwa w trybie i na zasadach określonych w art. 36o ustawy Prawo farmaceutyczne. W przypadku braku inicjatywy ze strony podmiotu odpowiedzialnego do dokonania zmian $\mathrm{w}$ dokumentacji produktu leczniczego znajdzie zastosowanie art. 36r tej ustawy. Zgodnie z tym przepisem, w przypadku powzięcia przez Prezesa Urzędu informacji o nowych istotnych zagrożeniach dotyczących bezpieczeństwa stosowania produktu leczniczego, Prezes Urzędu zobowiązuje podmiot odpowiedzialny do dokonania zmian w dokumentacji produktu leczniczego, określając termin na złożenie wniosku o dokonanie zmian. Informacja o zagrożeniu związanym z bezpieczeństwem stosowania produktów leczniczych może być również przekazana przez podmiot odpowiedzialny do publicznej wiadomości (art. 36y ustawy Prawo farmaceutyczne).

Określone sankcje przewidziano nie tylko w sytuacji uzyskania w toku porejestracyjnych badań produktów leczniczych informacji mających wpływ na bezpieczeństwo ich stosowania, ale także w przypadkach niespełnienia wymogów wynikających z art. 23b-23d ustawy Prawo farmaceutyczne. Niespełnienie przez podmiot odpowiedzialny dodatkowych warunków dotyczących bezpieczeństwa produktów leczniczych, przewidzianych w pozwoleniu na dopuszczenie produktów leczniczych do obrotu, w tym w zakresie przeprowadzenia badań bezpieczeństwa tych produktów, tj. wynikających z art. 23b-23c ustawy Prawo farmaceutyczne, a także obowiązków przeprowadzenia tych badań nałożonych już po dopuszczeniu leków do obrotu, tj. wynikających z art. 23d, skutkuje obligatoryjnym cofnięciem pozwolenia na dopuszczenie produktu leczniczego do obrotu na podstawie art. 33 ust. 1 pkt 7 tej ustawy. Restrykcyjność obligatoryjnej sankcji ustawodawca nieco złagodził, przewidując zamiast sankcji cofnięcia pozwolenia 
możliwość wydania decyzji o zawieszeniu ważności pozwolenia w przypadku, gdy wskazane wyżej naruszenie nie wiąże się z bezpośrednim zagrożeniem dla zdrowia publicznego.

\section{PODSUMOWANIE}

Każdy produkt leczniczy obok pożądanego efektu terapeutycznego może również powodować działania szkodliwe. Według jednego z farmakologów, Gustava Kuschinsky’ego, „gdy zapewnia się, że jakiś lek jest wolny od działań niepożądanych, pojawia się uzasadnione podejrzenie, że pozbawiony jest on także działania podstawowego" (za Masełbas 2008, 67; Wiela-Hojeńska, Łapiński 2010, 275). Dopuszczenie do obrotu danego produktu leczniczego, a wraz z nim zweryfikowanie bilansu korzyści i ryzyka użycia danego produktu leczniczego według stanu na dzień przed wprowadzeniem do obrotu, nie gwarantuje, że proporcja korzyści do ryzyka stosowania leku i jego profil bezpieczeństwa nie ulegnie zmianie po wprowadzeniu leku do obrotu i stosowaniu go w codziennej praktyce klinicznej. $Z$ tego też względu, w celu zidentyfikowania, opisania lub ilościowego określenia nowego lub zmieniającego się ryzyka stosowania danego produktu leczniczego, potwierdzenia profilu bezpieczeństwa produktu lub pomiaru skuteczności środków zarządzania ryzykiem użycia produktu leczniczego w ramach systemu nadzoru nad bezpieczeństwem farmakoterapii, przewidziano instytucję porejestracyjnych badań bezpieczeństwa produktów leczniczych, prowadzonych z inicjatywy podmiotu odpowiedzialnego bądź też w ramach obowiązków nałożonych na podmiot odpowiedzialny w pozwoleniu na dopuszczenie do obrotu produktu leczniczego lub po jego wydaniu. $\mathrm{Z}$ uwagi na nieinterwencyjny charakter tych badań wymogi formalnoprawne ich rozpoczęcia i prowadzenia nie zostały określone rygorystycznie, co ma stanowić zachętę do dobrowolnego inicjowania takich badań przez podmioty odpowiedzialne. $Z$ kolei możliwość zobligowania podmiotu do przeprowadzenia badań bezpieczeństwa pod rygorem cofnięcia pozwolenia na dopuszczenie do obrotu powinna stanowić skuteczny instrument gwarantujący bezpieczeństwo farmakoterapii. $Z$ danych udostępnionych przez Urząd Rejestracji Produktów Leczniczych, Wyrobów Medycznych i Produktów Biobójczych wynika jednakże, że Prezes Urzędu w ostatnich latach jedynie w kilku przypadkach zastosował przysługujące mu środki nadzoru nad bezpieczeństwem farmakoterapii. W latach 2015-2017 wydał tylko jedno pozwolenie na dopuszczenie do obrotu produktu leczniczego, przewidujące konieczność przeprowadzenia przez podmiot odpowiedzialny badań dotyczących bezpieczeństwa po wydaniu tego pozwolenia (tj. na podstawie art. 23c pkt 2 ustawy Prawo farmaceutyczne) oraz cztery pozwolenia na prowadzenie badania dotyczącego bezpieczeństwa przeprowadzanego po wydaniu pozwolenia, w wykonaniu obowiązków nałożonych przez Prezesa Urzędu, tj. w trybie art. 36u ustawy Prawo farmaceutyczne (Urząd Rejestracji 
Produktów Leczniczych, Wyrobów Medycznych i Produktów Biobójczych 2018). Wraz z rosnącą w polskim społeczeństwie świadomością, dotyczącą możliwości raportowania niepożądanych działań leków, instrumenty te mogą (i powinny) być w szerszym zakresie wykorzystywane do monitorowania bezpieczeństwa stosowania produktów leczniczych.

\section{BIBLIOGRAFIA}

European Medicines Agency. 2017. „Guideline on good pharmacovigilance practices (GVP) Module VIII - Post-authorisation safety studies (Rev 3), EMA/813938/2011 Rev 3”. http://www. ema.europa.eu/docs/en_GB/document_library/Scientific_guideline/2012/06/WC500129137. pdf [dostęp 10.03.2018].

Jabłoński, Michał. 2016. „Instytucje nadzoru nad bezpieczeństwem stosowania produktów leczniczych - pharmacovigilance". W Instytucje prawa farmaceutycznego. Red. Rafał Stankiewicz. 292-320. Warszawa: Wolters Kluwer.

Jagielska, Monika. 2015. „Komentarz do art. 23b”. W Prawo farmaceutyczne. Komentarz. Red. Leszek Ogiegło. 258-262. Warszawa: Wydawnictwo C.H. Beck.

Maciejczyk, Agata. 2008. „Wprowadzenie”. W Nadzór nad bezpieczeństwem farmakoterapii. Pharmacovigilance. Red. Iwona Łagocka, Agata Maciejczyk. 39-41. Warszawa: GCPpl, Oinpharma.

Masełbas, Wojciech. 2008. „Działania niepożądane leków: definicje, przyczyny, podział”. W Nadzór nad bezpieczeństwem farmakoterapii. Pharmacovigilance. Red. Iwona Łagocka, Agata Maciejczyk. 67-86. Warszawa: GCPpl, Oinpharma.

Masełbas, Wojciech. 2016. „Komentarz do art. 36u”. W Prawo farmaceutyczne. Komentarz. Red. Mariusz Kondrat. Warszawa: Wolters Kluwer, el/LEX.

Miłowska, Krystyna, Piotr Zięcik. 2016. „Komentarz do art. 37al”. W Prawo farmaceutyczne. Komentarz. Red. Wojciech L. Olszewski. Warszawa: Wolters Kluwer, el/LEX.

Urząd Rejestracji Produktów Leczniczych, Wyrobów Medycznych i Produktów Biobójczych. 2018. Pismo z dnia 13.04.2018 r. Znak: UR.DRL.RLK.460.0079.2018.

Wiela-Hojeńska, Anna, Łukasz Łapiński. 2010. „Niepożądane działania leków - rodzaje, podział, przyczyny i skutki ekonomiczne". Bezpieczeństwo Farmakoterapii 4 (66): 275-288.

\section{Akty prawne}

Dyrektywa 2001/83/WE Parlamentu Europejskiego i Rady z dnia 6 listopada 2001 r. w sprawie wspólnotowego kodeksu odnoszącego się do produktów leczniczych stosowanych u ludzi (Dz.Urz. UE L z 2001 r. Nr 311.67).

Dyrektywa 2010/84/UE Parlamentu Europejskiego i Rady z dnia 15 grudnia 2010 r. zmieniająca w zakresie nadzoru nad bezpieczeństwem farmakoterapii - dyrektywę 2001/83/WE w sprawie wspólnotowego kodeksu odnoszącego się do produktów leczniczych stosowanych u ludzi (Dz.Urz. UE L z 2010 r. Nr 348.74).

Rozporządzenie Parlamentu Europejskiego i Rady nr 1235/2010 z dnia 15 grudnia 2010 r. zmieniające - w zakresie nadzoru nad bezpieczeństwem farmakoterapii w odniesieniu do produktów leczniczych stosowanych u ludzi - rozporządzenie (WE) nr 726/2004 ustanawiające wspólnotowe procedury wydawania pozwoleń dla produktów leczniczych stosowanych u ludzi i do celów weterynaryjnych i nadzoru nad nimi oraz ustanawiające Europejską Agencję Leków i rozporządzenie (WE) nr 1394/2007 w sprawie produktów leczniczych terapii zaawansowanej (Dz.Urz. UE L z 2010 r. Nr 348.1). 
Rozporządzenie Parlamentu Europejskiego i Rady (UE) nr 536/2014 z dnia 16 kwietnia 2014 r. w sprawie badań klinicznych produktów leczniczych stosowanych u ludzi oraz uchylenia dyrektywy 2001/20/WE (Dz.Urz. UE L z 2014 r. Nr 158.1).

Ustawa z dnia 6 września 2001 r. Prawo farmaceutyczne (tekst jedn. Dz.U. z 2019 r., poz. 499 ze zm.). Ustawa z dnia 27 września 2013 r. o zmianie ustawy - Prawo farmaceutyczne oraz niektórych innych ustaw (Dz.U. z 2013 r., poz. 1245).

\title{
Agnieszka Rabiega-Przyłęcka
}

\section{POST-AUTHORISATION SAFETY STUDIES OF MEDICINAL PRODUCTS IN THE SYSTEM OF PHARMACOVIGILANCE}

\begin{abstract}
The aim of the article is to present the legal conditions of one of the elements of the pharmacovigilance system (pharmacotherapy safety) - post-authorisation safety studies of medicinal products. The analysis embraced requirements and principles of conducting safety tests of medicinal products after the authorisation for admitting them to trading in the light of, in particular, the Pharmaceutical Law of 6 September 2001.

Keywords: post-authorisation safety studies, safety of medicinal products, pharmacotherapy safety, pharmacovigilance, medicinal products, drug safety.
\end{abstract}

